\title{
Risk management in the organization of delivery of construction materials
}

\author{
Irina Misanova ${ }^{1, *}$, Dmitrij Tarasov ${ }^{2}$, Anastasia Safronova ${ }^{3}$, Alexey Astafiev ${ }^{1}$, and Ryszard \\ Świekatowsky ${ }^{4}$ \\ ${ }^{1}$ Department of Transport business management and intelligent systems, Russian University of \\ Transport, Moscow, Obraztsova str., 9, building 9, 127994. Russia \\ ${ }^{2}$ Department of Logistics and Marketing, Financial University under the Government of the Russian \\ Federation, 49 Leningradsky Prospekt, Moscow, 125993, Russia \\ ${ }^{3}$ Department of Innovative Entrepreneurship, Bauman Moscow State Technical University, Moscow, \\ Baumanskaja 5, 105005, Russia. Email: safronova21@mail.ru \\ ${ }^{4}$ School of Logistics, Poznan, 61-755, Republic of Poland
}

\begin{abstract}
In the article, the authors consider the problem of identifying and assessing the risks that arise when organizing the delivery of construction goods using the example of one of the main materials concrete mixture for transport and civil construction facilities. The relevance of this topic is due to the complexity and dynamism of the concrete mixture delivery system, during the functioning of which the emerging risks directly affect the quality of the supplied concrete mixture and technological processes. In this regard, the FMEA calculation and analytical method is propose, adapted to identify risks in the concrete mixture delivery system, which allows you to assess the criticality and significance of each identified type of risk (failure). Accounting, analysis and risk assessment constitute the toolkit of the risk management system risk management - aimed at increasing the efficiency of business processes by reducing the likelihood of adverse events and minimizing possible losses. At the same time, risk management is directly relate to making management decisions, often in conditions of uncertainty. Thus, risk assessment and risk optimization is an important and complex task.
\end{abstract}

\section{Introduction}

The effectiveness of the technology for managing the transportation of building materials largely depends on taking into account the risks arising in technological processes throughout the supply chain [1].

Scientist's economists distinguish two theories of risk - classical and neoclassical. The classical theory is risk as the mathematical expectation of losses that may arise because of a decision. In this option, risk is define as losses caused by the implementation of a particular solution. The neoclassical theory of economic risk is the probability of deviation from the set goals. Risk, as a rule, is perceive as a negative phenomenon, which only leads to undesirable consequences for the enterprise and business. However, the risk also has a

* Corresponding author: kino-rodina@mail.ru 
positive effect on the company, since the results or consequences can be neutral (zero) in relation to the subject of risk in the case of applying the methods of risk reduction.

Because of production and technological operations, the number and size of risks, which are diverse in nature, place of origin and nature, increase. Each functional area of business has its own "vector" of specific risks. The main reasons for the occurrence of risk are three environmental factors, determined by different situations or a set of circumstances: uncertainty, chance, counteraction, which must be reckoned with, anticipated, planned and, if possible, reduced, reduced and prevented.

"Modern methods make it possible to better assess the likelihood of achieving a goal or failure. However, until now the theoretical validity of indicators remains one of the problems, while the other is the static nature of the ratings, since they take into account past events and conditions, which may not exist" [2]. In turn, the efficiency of concrete mix delivery management depends on the ability to take into account the risks of a dynamic environment, including:

1. The inability of the customer to accept the concrete mix in the required quantity and at the right time;

2. Inability to unload concrete mixer trucks at a construction site on time;

3. Changing the order parameters or canceling it;

4. Threat of non-fulfillment of other orders just in time due to delays at the current customer's facility;

5. Changes in the traffic situation, the quality of the road surface, the condition of the access roads to the construction site;

6. Unforeseen breakdown of a concrete mixer and factory technological equipment;

7. Unfavorable weather conditions and other force majeure situations.

Material loss risks are associated with unforeseen additional costs or direct loss of materials, raw materials, equipment or products.

Work-related risks can be trigger by accidental events resulting in shorter working hours.

The risks of financial losses are associated with the need for additional costs in the form of payment of fines, additional taxes, loss of funds and securities.

Time risks arise when certain processes run longer than planned.

Risks of special types of losses (difficult to predict) are manifest in the form of damage to the environment or the health of employees, as well as in the case of other adverse moral and psychological impacts.

\section{Materials and Methods}

Today, there are various explanations for risks, our economists consider them from different angles of action from the nature of origin and impact on business to proposals for ways and methods of determining the likelihood of occurrence and their management.

In the process of organizing and managing the delivery of concrete mix, it is necessary to take into account all the risks arising at each stage of delivery and affecting the transportation process.

The theory and practice of risk management in organizing the delivery of construction materials are devoted to the works of Amani Suliman, D. Tarasov, D. Retnoningsih, Zhen Yu, Majercak J.

The research used the following methods: complex analysis, factor analysis, and analysis of official statistics, document analysis method, abstract-logical method, and ranking method, expert judgment method. 


\section{Results}

Risks negatively affect the technological processes of concrete mix delivery, which leads to a change in parameters such as [3]:

1) the quality of the concrete mix;

2) technology of production, loading, transportation, unloading and laying of concrete $\operatorname{mix}$

3) speed, duration and safety of transportation and others.

In this regard, for the convenience of identification and risk assessment, the delivery system will be present in the form of sequential functional blocks, each of which is a complex of interdependent technological processes and associated risks (Fig. 1).

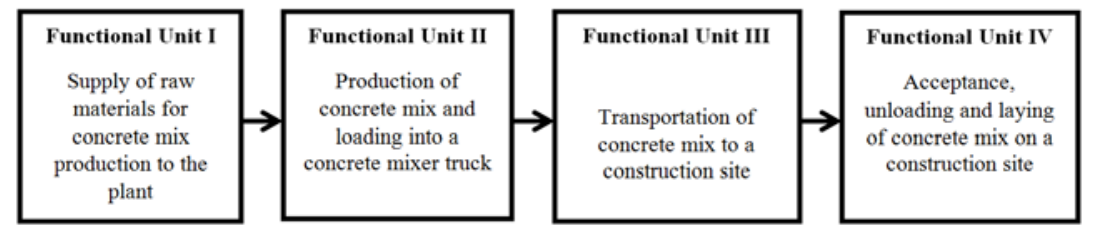

Fig. 1. Functional blocks of the concrete mix delivery system.

Risks negatively affect the technological processes of concrete mix delivery, which leads to a change in parameters such as:

1) the quality of the concrete mix; $\operatorname{mix}$

2) technology of production, loading, transportation, unloading and laying of concrete

3) speed, duration and safety of transportation and others.

Ultimately, violation of these parameters leads to a loss of concrete strength - a key property of the finished building material - and subsequently reduces the quality of the concrete building structure. Moreover, in order to ensure the efficiency of supply of construction materials with construction materials while maintaining proper quality, it is necessary to take into account the risks and manage them at all stages of the delivery of concrete mix.

In general, risk management should be carry out in the following sequence [4]:

1) identification of objective and subjective factors affecting a specific type of risk;

2) analysis of identified risks, assessment of a specific type of risk;

3) setting an acceptable level of risks;

4) analysis of individual operations to reduce each type of risk;

5) development of an action plan to optimize risks.

To optimize the risks in the process of concrete mix transportation control technology, we will apply the rank method. The proposed method based on the "Risk Priority Number" (RPN) indicator. [5]:

The indicator is a mixed measure of the criticality of failure and calculated as follows

$$
R P N=S \cdot O \cdot D
$$

where $S$ is the rank of the significance of the consequences of failure (Significance); $O$ is the probability of failure (Occurrence); $D$ - the ability to identify the problem (Detectability).

Assessment of indicators S, O, D is carry out on a 10-point scale (Table 1). 
Table 1. Criteria and assessment scale for indicators $S, O, D[8]$.

\begin{tabular}{|c|c|c|c|c|c|c|c|c|}
\hline \multicolumn{3}{|c|}{ Index $S$} & \multicolumn{3}{|c|}{ Index $O$} & \multicolumn{3}{|c|}{ Index $D$} \\
\hline Consequence & $\begin{array}{c}\text { Criterion of the importance of } \\
\text { consequences }\end{array}$ & Point & Risk probability & $\begin{array}{c}\text { Possible frequencies of } \\
\text { risks }\end{array}$ & Point & Detection & $\begin{array}{l}\text { Criteria: probability of } \\
\text { risk detection during } \\
\text { process control }\end{array}$ & Point \\
\hline $\begin{array}{l}\text { Dangerous without } \\
\text { warning }\end{array}$ & $\begin{array}{l}\text { It comes suddenly, Could } \\
\text { endanger workers. It leads to } \\
\text { instability of concrete structures } \\
\text { due to non-compliance with } \\
\text { mandatory requirements of } \\
\text { concrete mix quality } \\
\end{array}$ & 10 & $\begin{array}{l}\text { Very high: risks are } \\
\text { almost inevitable }\end{array}$ & $\begin{array}{c}\text { More than } 1 \text { out of } 2 \\
\text { of } \quad 1 \text { out of } 3\end{array}$ & $\begin{array}{c}10 \\
9\end{array}$ & Impracticablly & $\begin{array}{l}\text { No known control for risk } \\
\text { detection in concrete mix } \\
\text { delivery processes }\end{array}$ & 10 \\
\hline $\begin{array}{l}\text { Dangerous with } \\
\text { waming }\end{array}$ & Offensive can be foreseen & 9 & $\begin{array}{l}\text { High: maximum } \\
\text { risk probability }\end{array}$ & $\begin{array}{l}\text { More than } 1 \text { out of } 8 \\
\text { or } \quad 1 \text { out of } 20\end{array}$ & $\begin{array}{l}8 \\
7\end{array}$ & $\begin{array}{l}\text { Very } \\
\text { unsatisfactory }\end{array}$ & $\begin{array}{l}\text { It is almost impossible to } \\
\text { detect the type of risk by } \\
\text { the current control } \\
\text { methods }\end{array}$ & 9 \\
\hline Very significant & $\begin{array}{l}\text { Maximum process disturbances } \\
\text { during production, transportation } \\
\text { and laying of concrete mix. } 100 \% \\
\text { of the batch of concrete mix is } \\
\text { branded due to the impossibility } \\
\text { of correction }\end{array}$ & 8 & $\begin{array}{l}\text { Moderate: low risk } \\
\text { probability }\end{array}$ & $\begin{array}{l}\text { More than } 1 \text { out of } 80 \\
\text { or } 1 \text { out of } 400 \\
\text { or } 1 \text { out of } 2000\end{array}$ & $\begin{array}{l}6 \\
5 \\
4\end{array}$ & Unsatisfactory & $\begin{array}{l}\text { Extremely low probability } \\
\text { of detection of nisk type by } \\
\text { current control methods }\end{array}$ & 8 \\
\hline Significant & $\begin{array}{l}\text { Significant process dissuption } \\
\text { during production, transportation } \\
\text { and laying of concrete mix. Up to } \\
70 \% \text { of the concrete mix delivery } \\
\text { schedule is rejected due to } \\
\text { inability to adjust }\end{array}$ & 7 & $\begin{array}{l}\text { Low: low risk } \\
\text { probability }\end{array}$ & More 1 out of 5000 & 3 & Very low & $\begin{array}{l}\text { Very low probability of } \\
\text { detection of risk type by } \\
\text { current control methods }\end{array}$ & 7 \\
\hline Moderate & $\begin{array}{l}\text { Minor process disnuption during } \\
\text { production, transportation and } \\
\text { laying of concrete mix. Part of } \\
\text { batch of } 30 \% \text { supply of concrete } \\
\text { mix is rejected due to } \\
\text { impossibility of correction }\end{array}$ & 6 & $\begin{array}{l}\text { Very low: process } \\
\text { support risks }\end{array}$ & More 1 out of 150000 & 2 & Low & $\begin{array}{l}\text { Low probability of risk } \\
\text { type detection by current } \\
\text { control methods }\end{array}$ & 6 \\
\hline Weak & $\begin{array}{l}\text { Minor process disturbances } \\
\text { during production, transportation } \\
\text { and laying of concrete mix. It is } \\
\text { possible to partially retum to the } \\
\text { concrete plant to adjust the } \\
\text { composition }\end{array}$ & 5 & $\begin{array}{l}\text { Improbable: risks } \\
\text { are improbable }\end{array}$ & $\begin{array}{l}\text { Less than } 1 \text { out of } \\
1500000\end{array}$ & 1 & Moderate & $\begin{array}{l}\text { Moderate probability of } \\
\text { risk type detection by } \\
\text { current control methods }\end{array}$ & 5 \\
\hline Very weak & $\begin{array}{l}\text { Minimum process disturbances } \\
\text { during production, transportation } \\
\text { and laying of concrete mix. It is } \\
\text { possible to adjust the composition } \\
\text { of the supplied concrete mix }\end{array}$ & 4 & & & & $\begin{array}{c}\text { Fairly } \\
\text { moderate }\end{array}$ & $\begin{array}{l}\text { Moderate probability of } \\
\text { risk type detection by } \\
\text { current control methods }\end{array}$ & 4 \\
\hline Insignificant & $\begin{array}{l}\text { For such violations of } \\
\text { technological processes during the } \\
\text { production, transportation and } \\
\text { laying of concrete mix, minimal } \\
\text { adjustment of its composition is } \\
\text { possible }\end{array}$ & 3 & & & & Satisfactory & $\begin{array}{c}\text { High probability of } \\
\text { detection of defect type by } \\
\text { effective control methods }\end{array}$ & 3 \\
\hline Very insignificant & $\begin{array}{l}\text { This violation of technological } \\
\text { processes during the production, } \\
\text { transportation and laying of } \\
\text { concrete mix is allowed, since it } \\
\text { does not cany danger }\end{array}$ & 2 & & & & $\begin{array}{l}\text { Highly } \\
\text { satisfactory }\end{array}$ & $\begin{array}{l}\text { Very high probability of } \\
\text { detection of defect type by } \\
\text { effective control methods }\end{array}$ & 2 \\
\hline Absent & Without consequences & 1 & & & & $\begin{array}{l}\text { Almost } \\
\text { certainly }\end{array}$ & $\begin{array}{c}\text { The current control will } \\
\text { almost certainly reveal the } \\
\text { type of risk. For such } \\
\text { processes there are reliable } \\
\text { control methods }\end{array}$ & 1 \\
\hline
\end{tabular}

Before proceeding to the risk assessment in the process of concrete mix delivery technology, it is necessary to identify the factors of possible risks for all four functional blocks of the concrete mix delivery system (Fig. 2-5).

To determine the consequences of failures of the identified risk factors, it is proposed to use the FMEA (Failure Mode Effect Analysis) analysis method, which is used to "identify ways of failure of components, systems or processes that can lead to failure to perform their intended function" [6]. This FMEA method allows assessing the criticality and significance of each identified type of risk (failure) in the concrete delivery system. In this case, the criticality of risk is a set of signs that characterize the consequences of failure [7].

The classification of risks by criticality made in accordance with legal and regulatory requirements and the established priorities of the organization. 


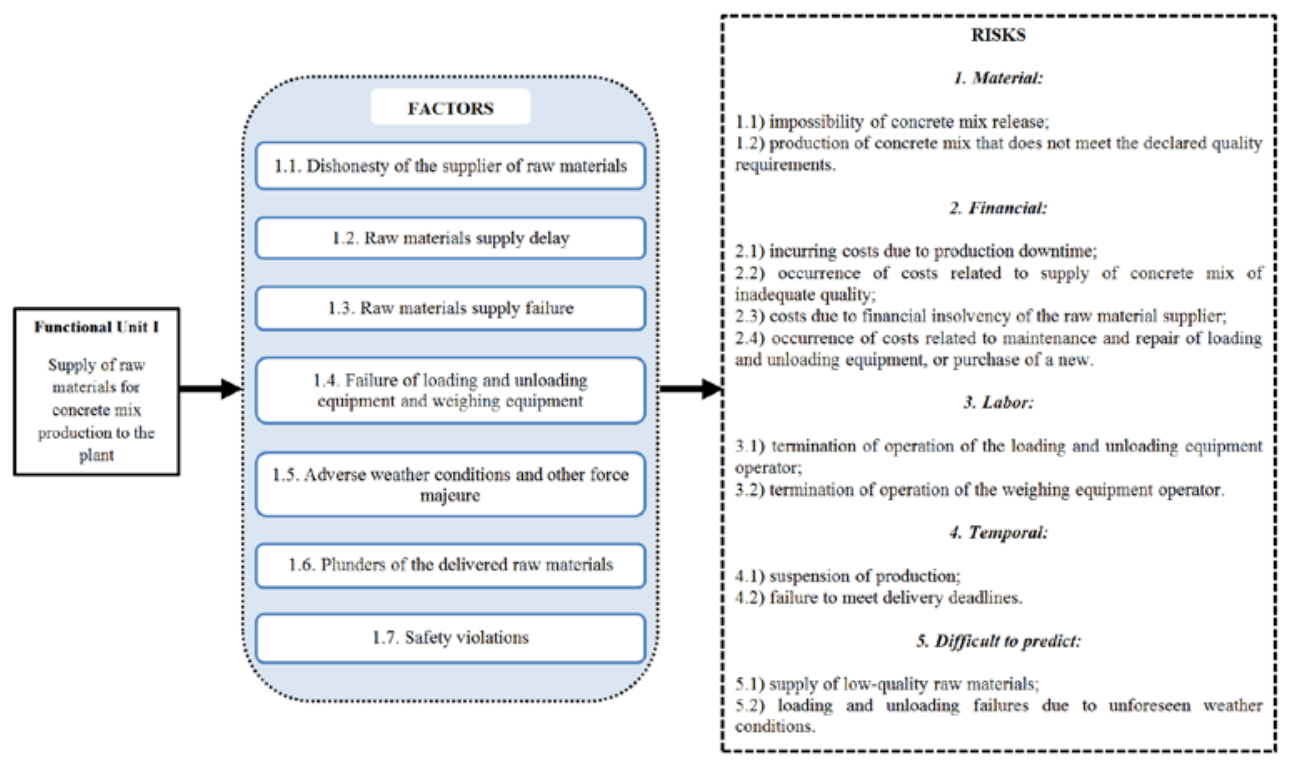

Fig. 2. Factor model of risks of functional block I.

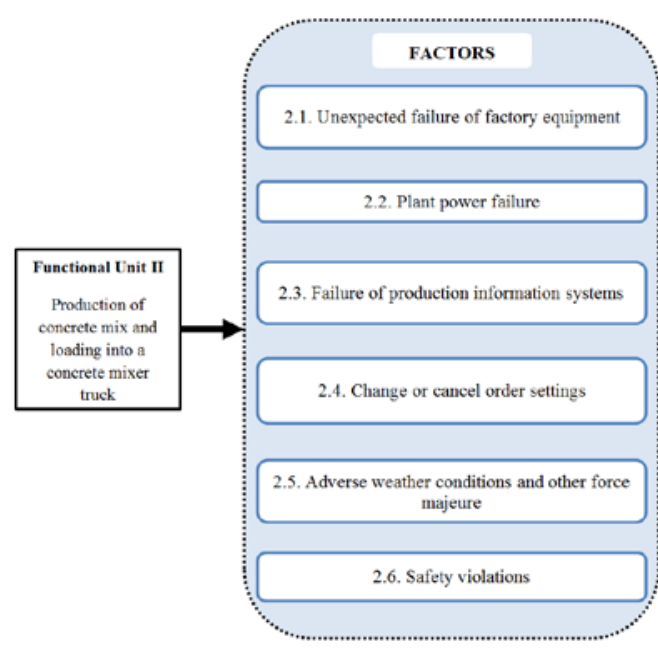

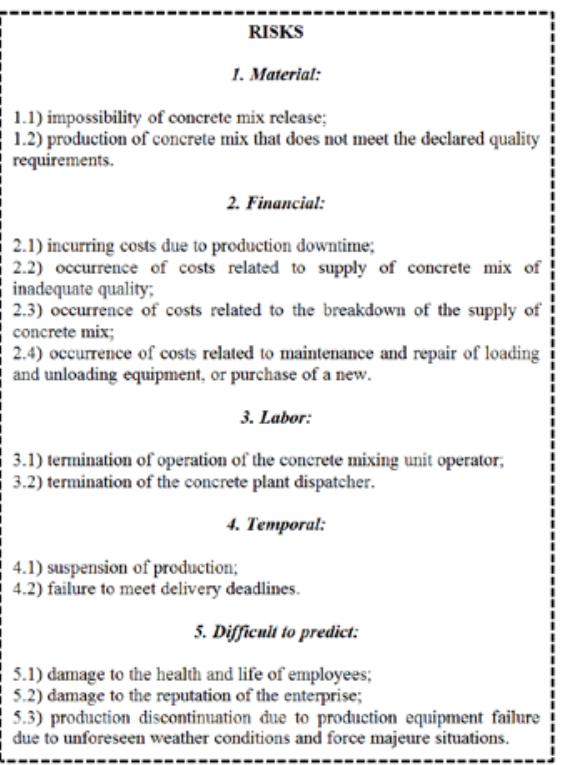

Fig. 3. Factor model of risks of functional block II. 


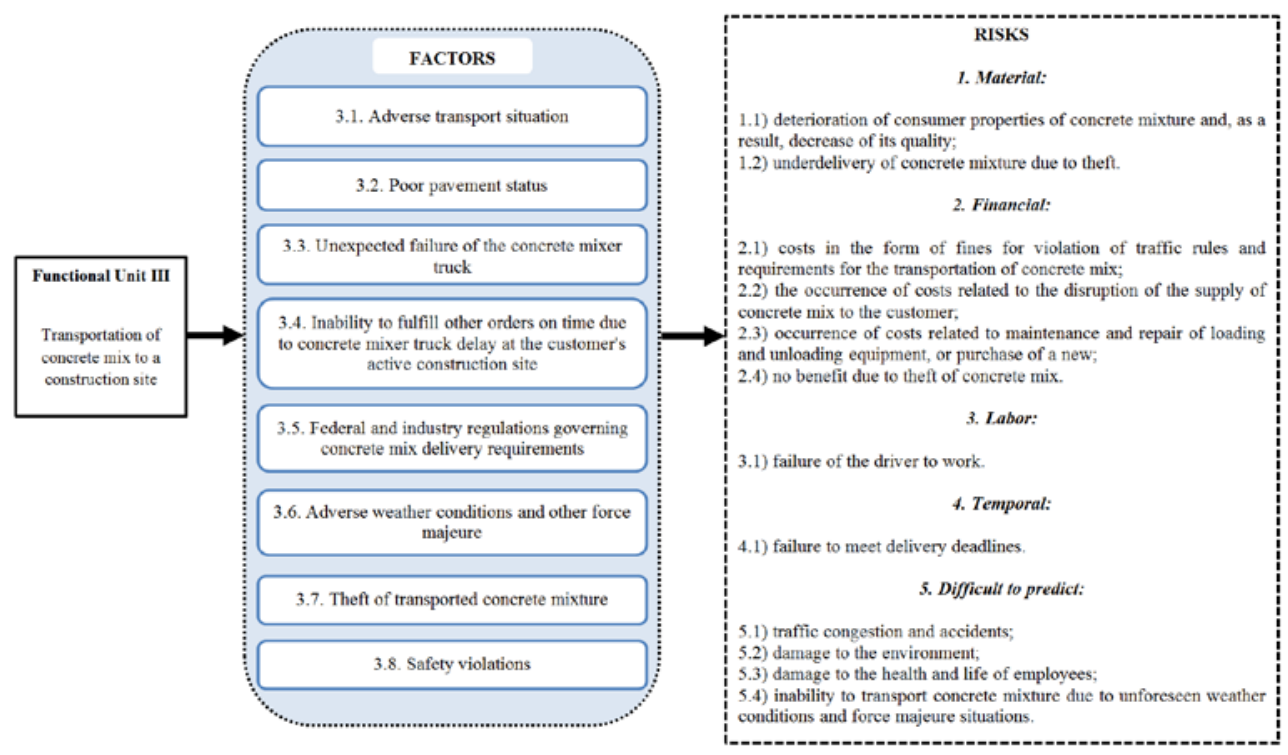

Fig. 4. Factor model of risks of functional block III.

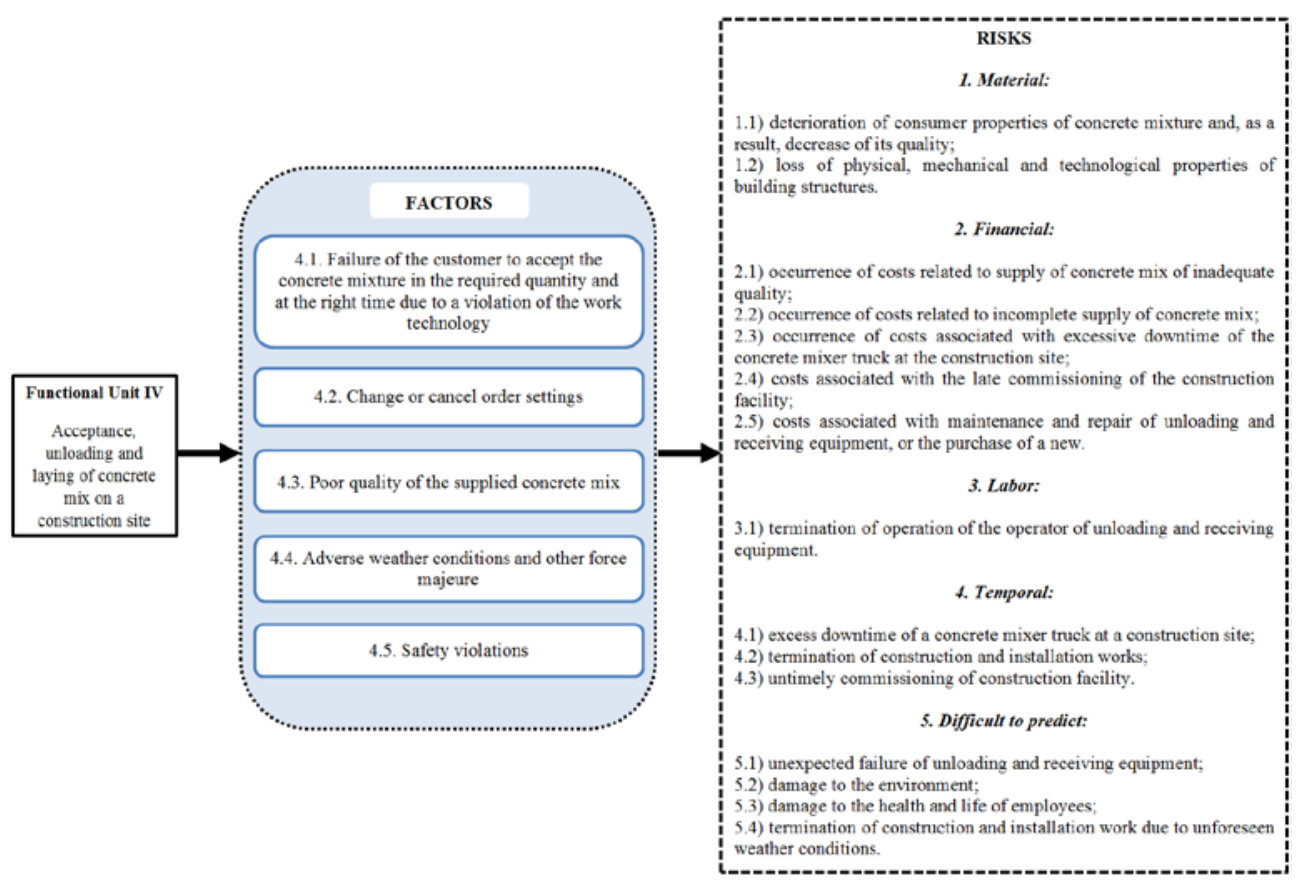

Fig. 5. Factor model of risks of functional block IV.

Using expert analysis, the identified risks assessed for each functional block of the concrete mix delivery system (Table 2 ).

Based on the data obtained, we will display the results of risk assessment graphically (Fig. 6). 
Table 2. Risk assessment for each functional block.

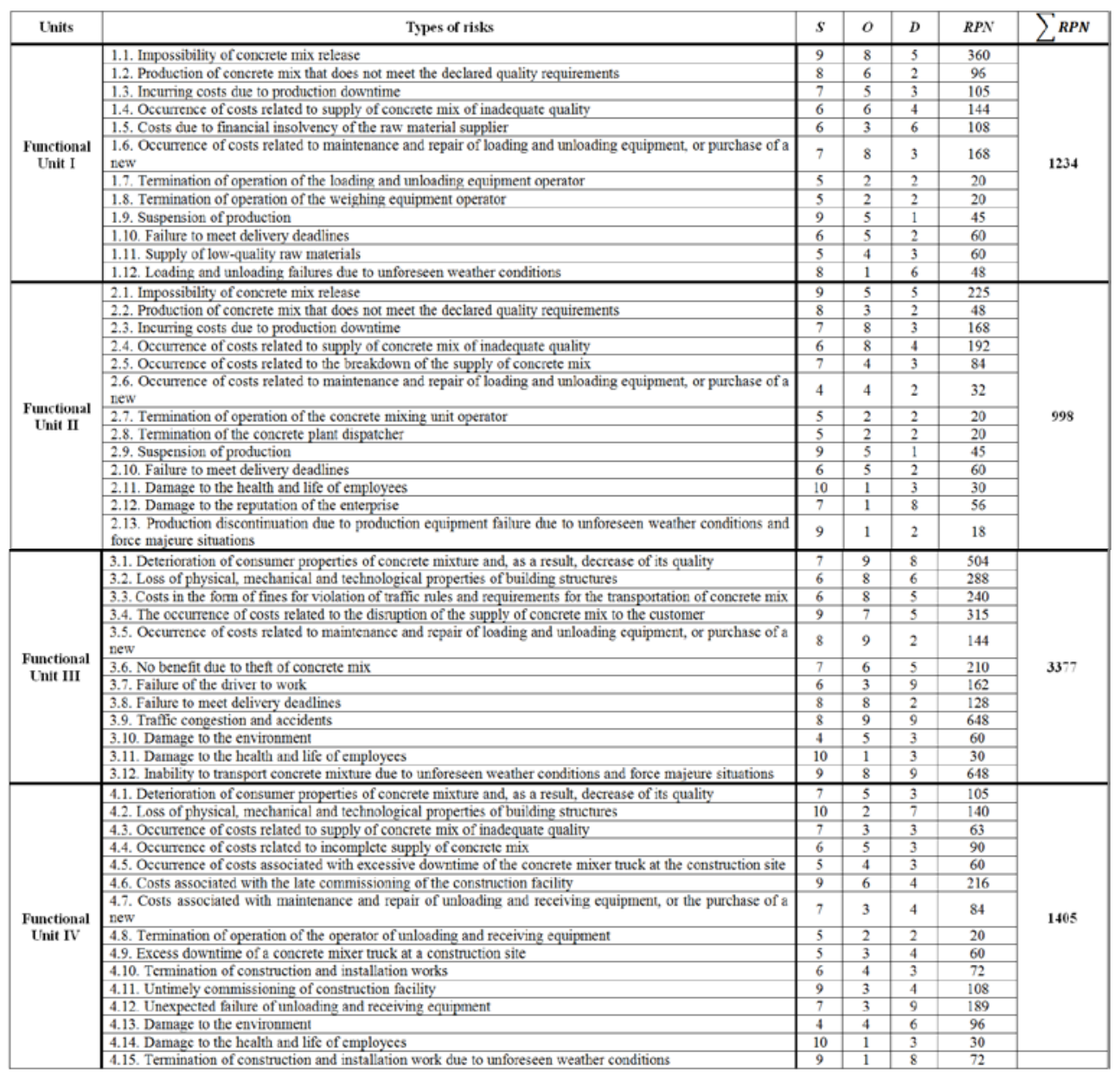

The assessment showed that the most risky is block III - the transportation of concrete mixture to the construction site, which confirms the vulnerability of this technological link in the concrete mixture delivery system and its significance of impact on the quality of the delivered material [8]. The least vulnerable stage is the production of the mixture at the concrete plant, since the parameters of the production processes are subject to maximum forecasting and control.

Considering the above, we note that measures to optimize risks in the process of management technology for the transportation of building materials affect the overall organization of the concrete mix delivery system. In addition, consequently, they lead to changes in the criticality parameters of failure associated with risks: the probability of a risk occurrence $(O)$ and the possibility of identifying a problem $(D)$. At the same time, a decrease in the first indicator and an increase in the second allows to a certain extent to minimize risks in each block of the delivery system [9]. 


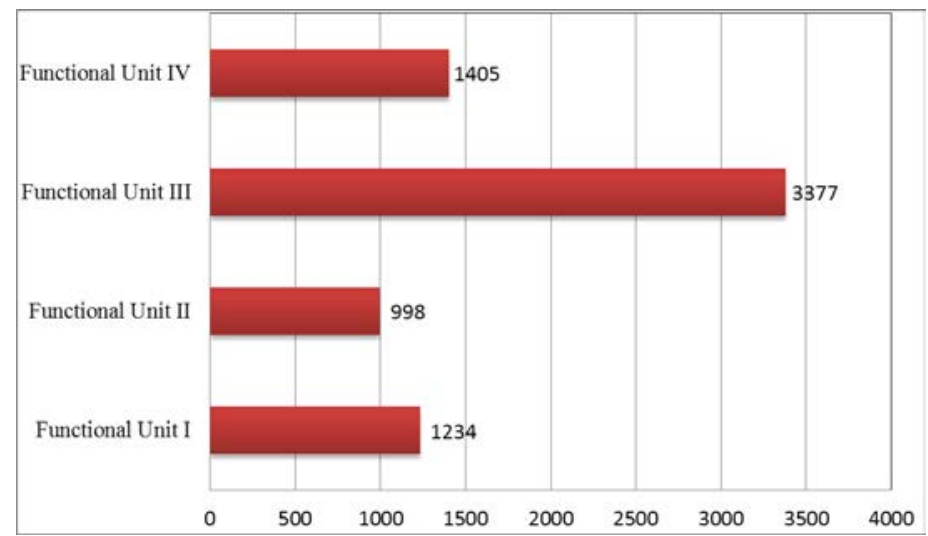

Fig. 6. Generalized values of the risk (vulnerability) of the functional blocks of the concrete mix delivery system

To measure the impact of optimization solutions on reducing risks in the technology of concrete mix delivery, an algorithm is propos for evaluating the effectiveness of their application [10]:

1. For all functional blocks, a comparison object is introduce - two options for the concrete mix delivery technology:

a) before applying optimization solutions $\left(T_{1}\right)$;

b) after their application $\left(T_{2}\right)$;

2. Types of risks in all blocks (see Table 2.) are present as indicators $W_{j i}$ for a comparative assessment of $T_{1}$ and $T_{2}$, where $j$ is the number of the functional block; $i-$ number of the type of risk in the corresponding block;

3. Using expert analysis for option $T_{2}$ on a 10-point scale, the results of changes in the indicators of each block assessed after the application of optimization measures;

4. The scores of indicators for options $T_{1}$ and $T_{2}$ brought together in a single table with the calculated $R P N$ and $\sum R P N$;

5. The coefficient of effectiveness of the influence of optimization decisions on minimizing risks is determined by comparing the total values $\sum R P N_{1}$ and $\sum R P N_{2}$ with the variants of the concrete mix delivery technology $T_{1}$ and $T_{2}$, respectively.

The results of the execution of points 1-4 of the described algorithm are summarize in table. 3 .

Based on the data obtained using the values $\sum R P N_{1}$ and $\sum R P N_{2}$, we present the results of risk assessment graphically (Fig. 7).

The study showed that the use of optimization solutions aimed at improving the concrete mix delivery system allows reducing the risk not only for the most vulnerable process - mix transportation, but also for all functional blocks in general:

1) supply to the plant of raw materials for the production of concrete mix - by $3.48 \%$;

2) production of concrete mix and loading into ABS - by $6.21 \%$;

3) transportation of concrete mix to a construction site - by $11.87 \%$;

4) acceptance, unloading and laying of concrete mix at a construction site - by $0.85 \%$.

Thus, in general, the degree of riskiness of the concrete mix delivery system using the improved technology is reduce by $7.38 \%$. In addition, as a result, a better quality delivery is ensure by increasing the transport speed and reducing the delivery time of the concrete mix. 
Table 3. Values of indicators of each functional block for two variants of concrete mix delivery technology

\begin{tabular}{|c|c|c|c|c|c|c|c|c|c|c|c|}
\hline \multirow{2}{*}{ Functional Units } & \multirow{2}{*}{$\begin{array}{c}\text { Indicators, } \\
\quad W_{j . i}\end{array}$} & \multicolumn{5}{|c|}{$\begin{array}{c}\text { Concrete mix delivery technology before } \\
\text { optimization }\left(T_{1}\right)\end{array}$} & \multicolumn{5}{|c|}{$\begin{array}{c}\text { Concrete mix delivery technology after } \\
\text { optimization }\left(T_{2}\right)\end{array}$} \\
\hline & & $s$ & $o$ & $\bar{D}$ & $R P N_{1}$ & $\sum R P N_{1}$ & $S^{\prime}$ & $O^{\prime}$ & $D^{\prime}$ & $R P N_{2}$ & $\sum R P N_{2}$ \\
\hline \multirow{12}{*}{$\begin{array}{l}\text { FUNCTIONAL } \\
\text { UNITS I }\end{array}$} & $W_{1,1}$ & 9 & 8 & 5 & 360 & \multirow{12}{*}{1234} & 9 & 7 & 6 & 378 & \multirow{12}{*}{1191} \\
\hline & $W_{12}$ & 8 & 6 & 2 & 96 & & 8 & 4 & 4 & 128 & \\
\hline & $W_{13}$ & 7 & 5 & 3 & 105 & & 7 & 4 & 3 & 84 & \\
\hline & $W_{14}$ & 6 & 6 & 4 & 144 & & 6 & 4 & 3 & 72 & \\
\hline & $W_{15}$ & 6 & 3 & 6 & 108 & & 6 & 3 & 6 & 108 & \\
\hline & $W_{1,6}$ & 7 & 8 & 3 & 168 & & 7 & 8 & 3 & 168 & \\
\hline & $W_{1.7}$ & 5 & 2 & 2 & 20 & & 5 & 2 & 2 & 20 & \\
\hline & $W_{18}$ & 5 & 2 & 2 & 20 & & 5 & 2 & 2 & 20 & \\
\hline & $W_{1,9}$ & 9 & 5 & 1 & 45 & & 9 & 4 & 2 & 72 & \\
\hline & $W_{1,10}$ & 6 & 5 & 2 & 60 & & 6 & 4 & 2 & 48 & \\
\hline & $W_{1.11}$ & 5 & 4 & 3 & 60 & & 5 & 3 & 3 & 45 & \\
\hline & $W_{1,12}$ & 8 & 1 & 6 & 48 & & 8 & 1 & 6 & 48 & \\
\hline \multirow{13}{*}{$\begin{array}{l}\text { FUNCTIONAL } \\
\text { UNITS II }\end{array}$} & $W_{2,1}$ & 9 & 5 & 5 & 225 & \multirow{13}{*}{998} & 9 & 4 & 6 & 216 & \multirow{13}{*}{936} \\
\hline & $W_{2,2}$ & 8 & 3 & 2 & 48 & & 8 & 3 & 3 & 72 & \\
\hline & $W_{23}$ & 7 & 8 & 3 & 168 & & 7 & 7 & 3 & 147 & \\
\hline & $W_{2,4}$ & 6 & 8 & 4 & 192 & & 6 & 7 & 3 & 126 & \\
\hline & $W_{2.5}$ & 7 & 4 & 3 & 84 & & 7 & 3 & 3 & 63 & \\
\hline & $W_{2,6}$ & 4 & 4 & 2 & 32 & & 4 & 4 & 3 & 48 & \\
\hline & $W_{27}$ & 5 & 2 & 2 & 20 & & 5 & 2 & 2 & 20 & \\
\hline & $W_{2.8}$ & 5 & 2 & 2 & 20 & & 5 & 2 & 2 & 20 & \\
\hline & $W_{2.9}$ & 9 & 5 & 1 & 45 & & 9 & 4 & 2 & 72 & \\
\hline & $W_{2,10}$ & 6 & 5 & 2 & 60 & & 6 & 4 & 2 & 48 & \\
\hline & $W_{2,11}$ & 10 & 1 & 3 & 30 & & 10 & 1 & 3 & 30 & \\
\hline & $W_{2,12}$ & 7 & 1 & 8 & 56 & & 7 & 1 & 8 & 56 & \\
\hline & $W_{2.13}$ & 9 & 1 & 2 & 18 & & 9 & 1 & 2 & 18 & \\
\hline \multirow{12}{*}{$\begin{array}{l}\text { FUNCTIONAL } \\
\text { UNITS III }\end{array}$} & $W_{3,1}$ & 7 & 9 & 8 & 504 & \multirow{12}{*}{3377} & 7 & 6 & 9 & 378 & \multirow{12}{*}{2976} \\
\hline & $W_{3,2}$ & 6 & 8 & 6 & 288 & & 6 & 8 & 6 & 288 & \\
\hline & $W_{3,3}$ & 6 & 8 & 5 & 240 & & 6 & 5 & 5 & 150 & \\
\hline & $W_{3,4}$ & 9 & 7 & 5 & 315 & & 9 & 5 & 6 & 270 & \\
\hline & $W_{3,5}$ & 8 & 9 & 2 & 144 & & 8 & 9 & 2 & 144 & \\
\hline & $W_{3,6}$ & 7 & 6 & 5 & 210 & & 7 & 6 & 5 & 210 & \\
\hline & $W_{3,7}$ & 6 & 3 & 9 & 162 & & 6 & 3 & 9 & 162 & \\
\hline & $W_{3,8}$ & 8 & 8 & 2 & 128 & & 8 & 6 & 3 & 144 & \\
\hline & $W_{39}$ & 8 & 9 & 9 & 648 & & 8 & 7 & 9 & 504 & \\
\hline & $W_{3,10}$ & 4 & 5 & 3 & 60 & & 4 & 3 & 4 & 48 & \\
\hline & $W_{3.11}$ & 10 & 1 & 3 & 30 & & 10 & 1 & 3 & 30 & \\
\hline & $W_{3,12}$ & 9 & 8 & 9 & 648 & & 9 & 8 & 9 & 648 & \\
\hline \multirow{15}{*}{$\begin{array}{l}\text { FUNCTIONAL } \\
\text { UNITS IV }\end{array}$} & $W_{31}$ & 7 & 5 & 3 & 105 & \multirow{15}{*}{1405} & 7 & 4 & 4 & 112 & \multirow{15}{*}{1393} \\
\hline & $W_{3,2}$ & 10 & 2 & 7 & 140 & & 10 & 2 & 9 & 180 & \\
\hline & $W_{3,3}$ & 7 & 3 & 3 & 63 & & 7 & 2 & 3 & 42 & \\
\hline & $W_{3,4}$ & 6 & 5 & 3 & 90 & & 6 & 4 & 4 & 96 & \\
\hline & $W_{3,5}$ & 5 & 4 & 3 & 60 & & 5 & 4 & 3 & 60 & \\
\hline & $W_{3.6}$ & 9 & 6 & 4 & 216 & & 9 & 5 & 4 & 180 & \\
\hline & $W_{3,7}$ & 7 & 3 & 4 & 84 & & 7 & 3 & 4 & 84 & \\
\hline & $W_{38}$ & 5 & 2 & 2 & 20 & & 5 & 2 & 2 & 20 & \\
\hline & $W_{3,8}$ & 5 & 3 & 4 & 60 & & 5 & 2 & 4 & 40 & \\
\hline & $W_{3,10}$ & 6 & 4 & 3 & 72 & & 6 & 6 & 4 & 144 & \\
\hline & $W_{3.11}$ & 9 & 3 & 4 & 108 & & 9 & 2 & 4 & 72 & \\
\hline & $W_{3,12}$ & 7 & 3 & 9 & 189 & & 7 & 3 & 9 & 189 & \\
\hline & $W_{3,13}$ & 4 & 4 & 6 & 96 & & 4 & 3 & 6 & 72 & \\
\hline & $W_{3,14}$ & 10 & 1 & 3 & 30 & & 10 & 1 & 3 & 30 & \\
\hline & $W_{3,15}$ & 9 & 1 & 8 & 72 & & 9 & 1 & 8 & 72 & \\
\hline
\end{tabular}

\section{Discussion}

The presented methodology for assessing risks seems to be a comprehensive, effective toolkit for improving the technology for managing the transportation of goods, in particular, when organizing the delivery of concrete mix.

Note that each company approaches with different criteria for the choice of methods and ways to optimize risks in managing the transportation of construction materials. It should be borne in mind that the desire to reduce risks generates new risks, which must also be manage. It is important to remember that not all risks can be mitigated, in particular the risks caused by macroeconomic processes. 


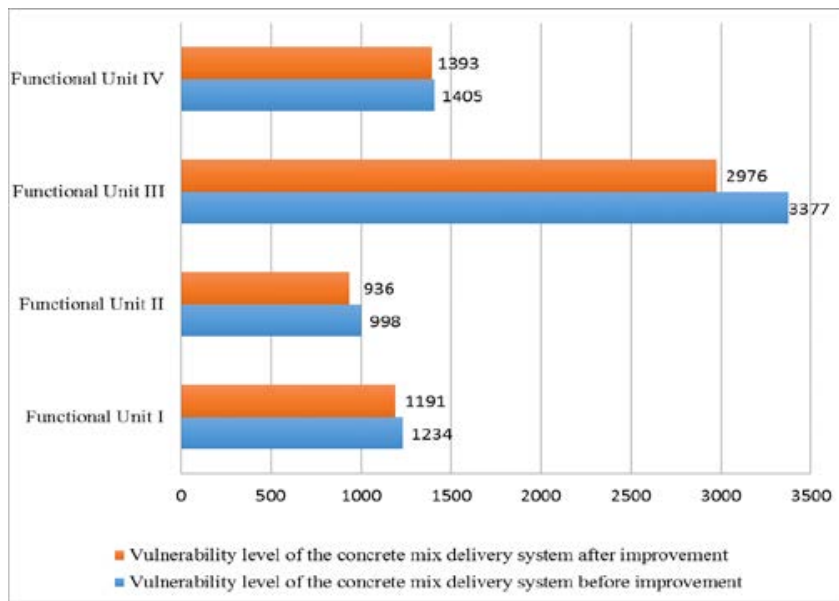

Fig. 7. Comparison of the generalized values of the risk (vulnerability) of the functional blocks of the concrete mix delivery system before and after optimization solutions

The risk management technique outlined in the article is recommend for practical implementation at transport and construction enterprises.

\section{References}

1. S.M. Reser, O.N. Larin, F. Wende, D.E. Tarasov. Models for calculating the cost of storing goods in logistics centers, in Transport: science, technology, management, 4 (2016)

2. I. Misanova. Analysis of political risks taking into account foreign experience, in Bulletin of the University. State University of Management, 17 (2014)

3. D. Tarasov. On increasing the efficiency of delivery of building materials to construction sites (for example, delivery of concrete mix), in Innovative transport, 2 (2019)

4. J. Majercak, S. Kudlac, M. Panak. Sustainable and Economically Efficient Five-point Supply Chain Management, in Proceedings of the 20th International Scientific Conference on Transport Means, 5-7 October 2016, Kaunas, Lithuania (2016)

5. Z.Y. Zhao, K. Xu, J. Zuo. Developing the International Construction Contracting Market: Enterprise Niche Approach, Journal of management in engineering, 33, 1, (2017)

6. A. Bu-Qammaz, I. Dikmen, M. Birgonul. Risk assessment of international construction projects using the analytic network process, Canadian journal of civil engineering, 7, 36 (2009)

7. P. Majercak, J. Majercak. Logistics Indicators for Measuring Performance of Logistics System in the Company, in 3rd International Conference on Education Reform and Management Innovation (ERMI 2015). Advances in Education Research, 78, (2015)

8. GOST R ISO / IEC 31010-2011 Risk management. Risk assessment methods, Standartinform (2012)

9. N. Rayesa, D. Retnoningsih, A. Aprilia. Risk mitigation of sustainable supply chain for food product based on apple commodity, RJOAS, Malanga, Indonesia, 96, 12, (2019)

10. S. Kudlac, V. Stefancova, J. Majercak. Using the Saaty Method and the FMEA Method for Evaluation of Constraints in Logistics Chain, in 10th International Scientific Conference on Transportation Science and Technology, 04-05 May, Vilnius, Lithuania, 187, (2017) 